\title{
Editorial
}

\section{Letter from the editor}

A abertura dos dados de pesquisa é hoje um dos aspectos centrais do movimento pela ciência aberta, colocando novos desafios do ponto de vista das infraestruturas, das capacitações, da sensibilização e, sobretudo, das condições em que esses dados são produzidos, acessados e (re)utilizados.

Longe de se tratar tão somente de um desafio à gestão, esta é uma agenda que remete a considerações no âmbito da (geo)política do conhecimento, da justiça cognitiva e da configuração de uma nova economia política em torno dos dados. Ela conecta-se ainda a outras agendas como a do governo aberto e da transparência de dados de modo amplo, o direito à privacidade e a novas estratégias de vigilantismo do Estado e do mercado.

Este número da Liinc em Revista, coordenado pelos professores Luana Salles e Luís Fernando Sayão, oferece um panorama da rica produção de pesquisas sobre essa temática, sobretudo aquelas desenvolvidas por pesquisadores brasileiros.

Prestamos aqui também uma especial homenagem à professora Maria Lucia Maciel, cofundadora e coeditora da Liinc em Revista, que nos deixou em outubro deste ano. Nossa querida parceira e amiga Luca deixa muita saudade e o desafio de fortalecer e renovar a proposta da revista de abrir espaço a temas emergentes e a perspectivas críticas no campo dos estudos sociais da informação e do conhecimento.

Sarita Albagli

Editora 